\title{
OVERALL CHARACTERISTIC OF METHODS AND METHODS OF CHOREOGRAPHIC TRAINING
}

\section{ЗАГАЛЬНА ХАРАКТЕРИСТИКА МЕТОДІВ І МЕТОДІВ ХОРЕОГРАФІЧНОЇ ПІДГОТОВКИ}

$6085 / 2021 / 41 / 1.20$

\section{Gritsenko O.E.,}

Teacher at the Department of Modern

and Sick Ball Choreography

Kharkov State Academy of Culture
The article deals with the characteristics of methods and techniques of choreographic training, ways to attract them to choreography, synthesizing a cycle of humanitarian disciplines, as well as the identification of pedagogical conditions for the activation of students' creative activity. The concepts of methods and techniques of choreographic training of schoolchildren are deepened. In the process of studying the disciplines of additional qualification, the artistic and creative activities of students are enriched by introducing methods into the educational process that will help future leaders of the children's choreographic team acquire theoretical knowledge and practical experience in working with children's choreographic groups - from their creation to the implementation of artistic and creative projects. In the formation of aesthetic and artistic culture of the individual, choreographic art is the most important aspect of aesthetic education. Classes in choreographic art contribute to the physical development of schoolchildren and enrich spiritually. The main task of the children's choreographic team is to introduce pupils to the basics of dance art, the development of their choreographic creativity. Pedagogical tasks of the head of the choreographic team: the formation of a child's stable interest in choreographic art through a passion for creativity; improving their common culture; development of a sense of rhythm, coordination of movements, orientation in space; education of taste, a valuable attitude to the environment and social reality, as well as the promotion of physical training, improvement of the body and physical fitness. The purpose of the existing programs on choreographic practice for children developed by the authors is the formation of initial choreographic skills, the assimilation of simple dance movements and ethodes; disclosure and development of creative potential, identification of gifted children and creation of conditions for their development. The development of choreographic skills of the student largely depends also on the assimilation of the material at the theoretical level.

Key words: choreographic activity, personality, creative activity, schoolchildren, methods, priyoms.

циплін, а також виявлення педагогічних умов активізації творчої діяльності учнів. Поглиблюються поняття методів та прийомів хореографрічного навчання школярів у закладах загальної середньої освіти. У процесі вивчення дисциплін додаткової кваліфрікаціі відбувається збагачення художньо-творчо діяльності студентів шляхом упровадження в освітній процес методів, що допоможуть майбутнім керівникам дитячого хореографрічного колективу набути теоретичні знання та практичний досвід роботи з дитя чими хореограсрічними колективами - від їхнього створення до здійснення художньотворчих проєктів. У фоормуванні естетичної і художньої культури особистості хореографрічне мистецтво є найважливішим аспектом естетичного виховання. Заняття хореографрічним мистецтвом сприяють фрізичному розвитку школярів та збагачують їх духовно. Музично-ритмічні рухи будуються на основі розвитку сприйняття художніх образів музичного супроводу та вміння відобразити їх у руханні. Тому в чинних програмах передбачено певний обсяг музично-ритмічних навичок і навичок виражального руху. Музично-ритмічні навички включають вправи на розвиток емочійної чутливості, реакції на зміну музичних образів, їхнього характеру, на зміну частин фрраз у структурі твору, а також на метроритмічні, динамічні, темпові зміни. Хореографрічне заняття в розумінні молодшого шкільного віку полягає в особистій і колективній репродукції життєвих прототипів на основ застосування засобів художньої виразності. Набуття навичок танцювального руху $\epsilon$ одним з основних завдань хореографрічної підготовки. Тому всі види хореографрічного мистецтва (танець, ритмічна гімнастика, аеробіка, образно-пластичні етюди, танцювальні вправи та мініатюри, спектаклі, що театралізуються тощо) мають ігровий характер. Основними педагогічними завданнями вчителя хореографрії у зв'язку із цим $є$ формування у школярів стійкого інтересу до хореографрічного мистецтва через захопленість, розвиток почуття ритму, координаціі рухів, орієнтування у просторі, виховання художнього смаку.

у статті розглядається характеристика методів і прийомів хореографрічного навчання, шляхи залучення їх до хореографрії, що синтезує в собі цикл гуманітарних дис-
Ключові слова: хореографрічна діяльність, особистість, творча активність, школяри, методu, прийоми.
The main task of the children's choreographic collective is to familiarize pupils with the basics of dance art, the development of their choreographic creativity. Pedagogical tasks of the head of the choreographic collective: the formation of a child's stable interest in the art of choreography through passion for creativity; raising the level of their general culture; development of a sense of rhythm, coordination of movements, orientation in space; fostering taste, respecting the environment and social reality, and promoting physical exercise, body and fitness. The purpose of the current programs on choreographic practice for children developed by the authors is the formation of initial choreographic skills, the assimilation of simple dance movements and ethodes; disclosure and development of creative potential, identification of gifted children and creation of conditions for their development. The development of the student's choreographic skills also largely depends on the assimilation of the material at the theoretical level. 
Analysis of recent research and publications. A broad understanding of the role and place of theatrical creativity in education is highlighted in the discussions of scientists and artists of the 70's of the last century. D. Khenkin, A. Konlovich, I. Timanov and others have proved that theatrical activity is a significant social and pedagogical phenomenon that reproduces the events of reality in artistic form. I. Zaitsev, M. Shevchenko, L. Masol, N. Miropolskaya and others have revealed a significant potential of theatrical art as a means of educating a personality. In the scientific literature it is also determined that the characteristic features of musical and creative activity are: initiative and creative need (O. Matyushkin), a creative impulse for the child's self-development (O. Khizhna), special personality abilities, which is manifested in purposeful activity, the ability to create (V. Starostin), self-realization of personality (O. Borisov). Scientists also paid due attention to the study of the psychological and pedagogical foundations of the upbringing of the musical and theatrical activity of the individua.

Highlighting previously unresolved parts of a common problem. At the same time, it should be noted that the problem of educating schoolchildren by means of choral activity has not yet been the subject of special research. Scientists do not sufficiently highlight the possibility of choreography as an educational technology for attracting students to humanistic values, the interaction of educational institutions and families in the process of raising a child by means of musical and theatrical activities has not been determined, directions of application The pedagogical experience of Ukrainian amateur theater in the modern pedagogical process has not been determined. It should also be noted that the program of children's choreographic groups does not sufficiently contribute to the active introduction of all schoolchildren to the moral values of universal and national culture; it is more spectacular than an appeal to deep spiritual and moral problems. These considerations were the reason for choosing the topic of the article.

Purpose of the article. To analyze scientific achievements on the problem of choreographic education of schoolchildren in the process of musical and pedagogical activity, to generalize their own practical pedagogical experience on this problem.

Presentation of the main material. The term "choreography" covers all types of dance art: dances of different nations, classical, ballroom, modern, etc. The acquisition of skills in dance movements is one of the main tasks of choreographic training. It is associated with the assimilation of elements of various movements, certain positions, poses, as well as drawings and figures of the dance. It is dance movements that form the basis of choreography. Educational programs of additional qualification disciplines take into account the peculiarities of children's choreography, performing-imitation and performingcreative musical-motor abilities of children. Taking into account the changes in the elementary school of Ukraine, special attention is paid to the professional preparation of schoolchildren for plastic improvisation, its application in play activities in art lessons, and choreographic terminology. This is also due to the fact that in the art programs of the ZSSO (authors L. Masol, N. Lemesheva, O. Lobova, G. Kizilova, L. Aristov) there are lesson topics dedicated to dance art, for example, "The Kingdom of Ballroom Dancing" (3 class), "Musical fairy tale in dance", "Such different dances" (dance, minuet, dance), "Dance colors", "Ballet magicians", "Ballet fairy tale", "Magic", "Beauty of movement" (1'st grade) and others [1, p. 56].

Learning ball choreography will be effective if intertransparent communication is realized. In the process of studying the dance material, the knowledge gained in the lessons of history, geography and art culture deepens and expands. Literature, for example, provides rich illustrative material that makes it possible to understand the problem of studying and preserving the historical heritage. Novels, stories, poems contribute to the formation of ideas about the types of dances, the manner of their performance, the rules of etiquette, the costumes of the performers. And vice versa, studying the history of dance culture helps students better understand the character of the heroes of literary works, learn about the life and morality of society. Special regulation in the dance of the relationship between a gentleman and a lady helps students to feel the confidence of a man, characteristic of that time, his responsibility to a partner, and girls to feel lightness and lightness, which are now lacking. in modern youth. [3, p. 38]. Choreographic creativity of schoolchildren is allowed to be successfully organized in various types of educational institutions (general education school, out-of-school educational institution) and in various socio-cultural spheres (family, leisure with peers, etc.). Amateur creativity actively contributes to the development of the emotional sphere of children, creates a conditional reality in which the student learns to identify and develop his needs and interests. Moreover, with the help of the mechanisms of transformation into images of the heroes of the play, there is a relaxed involuntary assimilation of moral norms, the development of spiritual feelings, creative abilities. [4, p. 72]. Art creates a kind of balance between the demands of life and the psychological, physiological and social capabilities of a person. Successful teaching by means of choreographic art helps to expand the range of life opportunities for schoolchildren. This includes mastering a wider range of social repertoires, as art is capable of acting as a vehicle for the internationalization of certain norms, positions and roles.

Organization of choreographic classes, in which educational technology is aimed at developing 
the structural components of their value orientations (cognitive, emotional-semantic, motivationalactivity) in their harmonious unity. In addition, the development of the emotional-semantic component in choreographic activity presupposes the formation of a positive emotional perception of values in schoolchildren and their understanding as personally significant.

For the development of the emotional-semantic component, scientists L. Zygotsky, G. Kostyushko, $\mathrm{N}$. Miropolskaya suggest using, first of all, the following methods: 1) creating educational situations; 2) example (actions, actions of goodies, personal example of a teacher); 3) enthusiasm; 4) promotion (support, approval of the child; 5) creation and playing of ethodes, the topics of which are related to the problems of the personal life and everyday life of indigenous people; 6 ) oral description of events or characters, drawing; 7) discussions, exchange of views on the perception of events, actions of the heroes of the performances.

The efforts of teachers should be aimed at creating a positive emotional atmosphere in the team, deepening children's knowledge about the emotional saturation of perception and human impressions about themselves and the world around them, developing their need for emotional and aesthetic experiences. Moreover, the work on the formation of the emotional-semantic sphere should be built taking into account the sources of emotional infection: the emotionality of the material of theatrical classes, the emotionality of the teacher, the emotional atmosphere of interpersonal communication of children [5, p. 12]. In order to teach schoolchildren by means of choreographic activity, each teacher must remember that when organizing the dance creativity of schoolchildren, one should not allow a violation of the integral aesthetic attitude to the performance as a synthesis of arts. After all, all children are different, they have a unique type of artistic ability: musical, literary, dramatic, plastic, visual, as well as individual experience gained in the classroom in a certain type of artistic creativity.

Conclusions. All schoolchildren are interested in choreographic art, attracting them to a certain type of stage creativity, it is necessary to take into account the peculiarities of the aesthetic attitude of children of every age to musical and theatrical art. And this, as a rule, does not coincide in the genre preferences of children-spectators and children-creators, which has objective origins in the nature of perception, the nature of performing creativity, physical and psychological performing abilities of schoolchildren. In particular, the viewer considers a puppet and dramatic performance the most attractive than a musical and an opera for a junior schoolchild. Summing up the above, it should be noted that theatrical activity presupposes and requires the upbringing of empathic culture in schoolchildren, the gift of knowledge of another person, based on such universal human qualities as the ability to compassion and empathy, tolerance, goodwill. All schoolchildren are interested in choreographic art, attracting them to a certain type of stage creativity, it is necessary to take into account the peculiarities of the aesthetic attitude of children of every age to musical and theatrical art. And this, as a rule, does not coincide in the genre preferences of children-spectators and children-creators, which has objective origins in the nature of perception, the nature of performing creativity, physical and psychological performing abilities of schoolchildren. In particular, the viewer considers a puppet and dramatic performance the most attractive than a musical and an opera for a junior schoolchild.

Summing up the above, it should be noted that theatrical activity presupposes and requires the education of schoolchildren of empathic culture, knowledge of another person, based on such universal human qualities as the ability to compassion and empathy, tolerance, benevolence, given the insufficient scientific study of the problem posed.

\section{REFERENCES}

1. Вертохина А., Самакаева М. Педагогические условия активизации профессионального самоопределения учащихся детской хореографической школы : монографияя ; ФГБОУ ВПО «Уральский государственный педагогический университет». Екатеринбург, 2013. 174 с.

2. Мартиненко О. Формування професійної компетентності майбутніх учителів хореограсрії в процесі фрахової підготовки. Розвиток художньо-естетичного світогляду майбутніх учителів хореографрії на основі інтегративного підходу : колективна монографрія /за ред. О. Мартиненко. Бердянськ, 2015. C. 6-49.

3. Сердюк Т. Художньо-естетична школа майбутніх учителів хореограсрії: формування досвіду : монограсрія. Донецьк : ЛАНДОН-XXI, 2011. 273 с.

4. Stones E. Psychopedagogy. Psychological Theory and the Practice of Teaching. 2000. P. 400.

5. Шабаліна О. Підготовка хореограсрічних кадрів у контексті переходу до системи відкритої освіти. Хореограсрія XXI століття: мистецький та освітній потенціал : матеріали Всеукраїнської науковопрактичної консеренції, 15-16 квітня, 2016. Київ : КНУКіМ, 2016. С. 290-293.

6. Шевчук А. Дитяча хореографрія : навчальнометодичний посібник. 3-тє вид., зі змін. та доповн. Тернопіль : Мандрівець, 2016. 288 с. 